\title{
Treasury Single Account and Fraud Management in Nigeria: Benefits and Challenges
}

\author{
ARUKWE C. Maureen ${ }^{1}$, OKORO Deborah P. ${ }^{2}$, ENEH Nnajiofor Cyrus ${ }^{3}$ \\ (correspondence) \\ ${ }^{1,3}$ Department of Management, ${ }^{2}$ Department of Marketing, University of Nigeria, Enugu Campus
}

\begin{abstract}
Treasury systems are designed to manage several critical aspects of public expenditure management. Key treasury system functions include financial planning, control of the budgetary process and management of government cash flow. However, for any treasury system to be effective, government has to ensure that it has sufficient liquidity to deal with payments, while ensuring that such liquidity costs are kept within the barest minimum. TSA is a (system of) unified structure of government bank accounts enabling optimal utilization and consolidation of government cash resources. In TSA a bank account or a set of linked bank accounts is used for all government transactions all its receipts and payments and gets a consolidated view of its cash position at any given time. This study investigates Treasury Single Account (TSA) and Fraud Management: Benefits and Challenges in Nigeria. Adopting a survey design, the study made use of primary data collected mainly through administering a set of questionnaire tol04employeesofselected three Corporate Affairs Commissions in South-East, Nigeria comprising Enugu, Imo and Abia.100copiesofthequestionnaireoutof the total number of retrieved copies of questionnaire were validly completed and useful for analyses. Findings interlaid revealed that: TSA significantly reduced the incidence of fraud in public enterprises; TSA in public enterprises to a large extent reduces the credit creation of deposit money banks. The study recommends that the TSA policy will be effective if, the Fiscal Sunshine Bill is to be put in place, and if enacted will open up all financial activities of government in a way that there will be no more hiding place for those who divert or loot government money. Just like the Fiscal Sunshine Act is in place with budgeting process, implementation and contract awards, should be open for Nigerians to see how both revenues are generated and how public money is being spent by those in government, and why; Government should overhaul the capacity of the Federal Ministry of Finance and the CBN in order to cope effectively with the challenges associated with enforcement of the provisions of the TSA.
\end{abstract}

Keywords: Treasury Single Account, Fraud management, Benefit and challenges, CBN.

\section{INTRODUCTION}

Treasury Single Account (TSA)by the Federal Government of Nigeria (FGN) is a public accounting system under which all government revenues, receipts and income are collected into one single account, which is usually maintained by the country's Central Bank and all payments done through the same account. The purpose is mainly to ensure accountability of government revenue, enhance transparency and avoid misappropriation of public funds (Bashir, 2016). Government banking arrangement is a very important component for efficient management and control of government's cash resources. Such banking maintenance should be utilized to reduce the cost of government borrowing and increase the opportunity cost of cash resources. The purpose of this banking arrangement is to ensure that all cash received is available for carrying out government's expenditure programs and making payments in a timely fashion while promoting transparency.

Many emerging markets and low-income countries such as Ghana and Sierra-Leone have fragmented systems for handling government receipts and payments (Pattanayak \& Faiboim, 2010; Bashir, 2015). In these nations, the 
DOI: $\underline{10.51386 / 25815946 / i j s m s-v 4 i 3 p 123}$

ministry of finance/treasury do not have a centralised control and unified view over the cash resources of the government. As a result, this cash lies dormant for extended periods in numerous bank accounts held by ministries, department and agencies while the government continues to borrow to carry out its budgetary functions (Adeolu, 2015). One major policy implementation that has great effect on major decisions and actions of public corporations and impact public enterprises' fraud management is the Treasury Single Account (TSA) policy. Hence, the evaluation of the benefits and challenges of a TSA to public enterprises has become imperative and assumed heightened significance in Nigeria today.

In most developed countries,such as France, United Kingdom and United States, almost all the receipts are consolidated daily in a Treasury Single Account (TSA), which is secure under the control of the Treasury or the Ministry of Finance (MoF),depending on the country (Lan, 2009). Through the TSA, all revenue payments and receipts will be done through the consolidated Revenue Account (CRA) at the Central Bank of Nigeria. Through the TSA the Federal Government via MoF and the Accountant General of the Federation will have a full overview of the financial state of the country. When establishing a TSA, the government payment function can be centralized with all disbursements made directly from the main operational account of the TSA at the central bank. Alternatively, payments can be decentralized, and made by spending ministries from accounts held in commercial banks, also known as Zero Balance Accounts (Lan, 2009), (Pattanayak,\& Fainboim, 2011). The balances in ministries' bank accounts are moved into the TSA every day and the government's cash manager ensures that only a minimum end-of-day balance remains in the TSA's main account at the central bank. Temporary cash surplus is usually remunerated by the central bank or placed in financial market instruments.

The Nigerian Federal Government's directive to all revenue-generating agencies to close their accounts with commercial banks by $7^{\text {th }}$ August, 2015 and transfer same into a Consolidated Revenue Fund of the Federation andwith September 15, 2015 as the deadline for total compliance. TSA as a new electronic revenue collecting platform inaugurated recently by President Buhari has continued to generate issues across the country; prominent among these issues, include the adverse effect of TSA on commercial banks, due to the movement of funds to the CRA.

Any government lacking effective control over its cash resources can result in institutional deficiencies in multiple ways. Idle cash balances left in bank accounts often fail to earn market-related remuneration (Sailendra, P. \& Israel, F. 2010). The government, not being aware of these resources, incurs unnecessary borrowing costs on raising funds to cover a perceived cash shortage while the Ministries, Department and Agencies (MDAs), are fraudulently using the cash for their own personal needs. This will prevent government from implementing all their policies because of inadequate fund in government account.

However, implementing a unified structure of a government's bank accounts via a treasury single account (TSA) will improve control and cash management. Therefore, it should receive priority in any of the public financial management (PFM) reform agenda. The TSA also facilitates better monetary and fiscal policy coordination and better reconciliation of banking and fiscal data, which in turn improves the quality of fiscal information. In view of these problems, the implementation of an effective TSA will significantly manage fraud in public enterprises and boost the economy.It is in view of the already mentioned inherent challenges of financial leakages encountered in the remittance, revenue generation, and absence of transparency, revenue loss as well as mismanagement by revenue-generating agencies in the public enterprise that the researchers aimed to carry out this study

\section{REVIEWOFRELATED LITERATURE}

\section{Overview of the Concept of TSA}

Treasury systems are designed to manage several critical aspects of public expenditure management. Key treasury system functions include financial planning, control of the budgetary process and management of government cash flow. However, for any treasury system to be effective, government has to ensure that it has sufficient liquidity to deal with payments, while ensuring that such liquidity costs are kept within the barest minimum (Tandberg, M.E., 
DOI: $\underline{10.51386 / 25815946 / i j s m s-v 4 i 3 p 123}$

Volume: 4 Issue: 3

May to June 2021

www.ijsmsjournal.org

2005). This is where Treasury Single Account (TSA) comes into play; as it enables the treasury system achieve the aforementioned, ensuring better cash management.

TSA is a unified structure of all government bank accounts enabling optimal utilization and consolidation of government cash resources. Simply put, it is a bank account or a set of linked bank accounts through which the government transacts all its payments and receipts and gets a consolidated view of its cash position at any given time (Pattanayak \& Faiboimi, 2010; Onyekpere, 2015). TSA is a single account made from subsidiary accounts of public enterprises all linked to a main account such that, transactions are effected in the subsidiary accounts but closing balances on these subsidiary accounts are transferred to the main account, at the end of each day of transaction. With the implementation of the TSA, Ministries, Departments and Agencies (MDAs) will maintain their individual accounts with the deposit money banks, but daily funding of their expenses are made from the main account, which residesin the Central Bank, just as their closing balances at the end of day are transferred to the main account (Chukwu, 2015).It is a public accounting system under which all the revenues of the government, receipts and income are collected into one single account usually maintained by the country's Central Bank and all payments done through this account as well. It primarily ensures accountability of government revenue, enhance transparency and avoid misappropriation of public funds (Adeolu, 2015).

In Nigeria, a presidential directive was given in a bid to adopt best-practices of fund management in governance and public institutions, so as to end mismanagement of public funds which were usually kept in several fragmented accounts for government revenues, incomes and receipts, which in the recent past has meant the loss or leakages of authorized income meant for the federation account. TSA is a tool and process for effective management of the finances of the government, cash position and banking. In accordance with the name, it unifies and pools all government accounts through a treasury single account (Onyekpere, 2015).However, this TSA is not just pooling all of government's funds into a single account, individual cash transaction are distinguished for reporting and control purposes. Hence, itenables the treasury to delink management of cash from control at a transaction level (Sailendra, P. \& Israel, F. 2010).

The consolidation of all accounts into a TSA paves way for the timely capture and payment of all due revenues into government account without the multiple banking intermediations and arrangements. This accounting system prevents revenue leakages in terms of mismanagement and revenue loss by operators of all agencies that generate revenue. With this comes optimal cash management practices because the treasury can at all times have an overall view of the finances and cash position of the government, as against when the cash were scattered in different accounts of Ministries, Department and Agencies (MDAs) and has to be laboriously pooled together to get the overall picture. Also, it will reduce the cost of borrowing by government and its agencies, as the government will likely be in the surplus at most times of the year because there would be no more diversion of government fund (Onyekpere, 2015). TSA will make government's coffer to burst.

Again, the main tool of cash management for efficient management of the Government's cash position is TSA. Prior to the TSA implementation, government was incurring financial cost on debit balances in some MDA's accounts while it was earning close to nothing on the credit balances of other MDAs. TSA equally means that the net balances on all the MDA accounts will now reside with the Central Bank; hence, the government will avoid incurring interest costs when it has positive net position. TSA is a unified arrangement of government bank account enabling consolidation and optimal utilization of government cash capital. A TSA therefore is considered as a prerequisite for modern cash management and is an effective tool for the ministry of finance/treasury to establish oversight and centralized control over government's cash resources (Yusuf and Chiejina, 2015).

\section{Features of a Treasury Single (TSA}

A full-fledged TSA shares three essential features in line with Sailendra and Israel (2010).

Unified Banking Arrangement: TSA is a unified structure of government bank accounts that gives a consolidated view of government cash resources. All banking arrangementsof the the government should be unified, to enable 
DOI: $\underline{10.51386 / 25815946 / i j s m s-v 4 i 3 p 123}$

ministry of finance or treasury exercise oversight of government cash flows in and out of these bank accounts. A unified structure of government bank accounts allow complete fungibility of all finance and cash resources, including a real-time basis if electronic banking is in place. The structure of the TSA can contain ledger subaccounts in a single banking institution (not necessarily a central bank), and can accommodate external zero balance accounts (ZBAs) in some commercial banks (Sailendra and Israel, 2010).

Non-Interference (Centralization) on Treasury Oversight: The treasury, as the chief financial agent of the government, should manage the government's cash and debt positions to ensure that sufficient funds are available to meet financial obligations, idle cash is efficiently invested, and debt is optimally issued according to the appropriate statutes. Secondly, no other government agency can operates bank accounts that is not within the over sight of the treasury. All the options for accessing and operating the TSA are mainly dependent upon institutional structures and payment settlement systems(Sailendra and Israel, 2010).

Comprehensive Consolidation of Government Cash Resources: The consolidation of government cash resources should encompass all government cash resources and be comprehensive, both budgetary and extra-budgetary. This means that all public duty irrespective of whether the matching cash flows are subject to budgetary control or not (e.g., in the case of reserve funds, earmarked funds and other off-budget/extra budgetary funds) should be under the control of the TSA. The total cash balance in the TSA main account is maintained at a level that sufficient to meet daily operational requirement of the government together with other operational contingencies and buffers to meet fiscal volatility. However, some funds, especially those controlled by donors, and it a challenge to integrate all the loans from multilateral institutions into the TSA. However, some donors have agreed to the various arrangements to integrate their flow of aid with the TSA in several countries (Sailendra and Israel, 2010).

\section{Objectives of Treasury Single Account}

The primary aim of a TSA is to ensure effective total control over the cash balances of the government. The use of TSA arrangements to consolidate cash resources facilitates government cash management by reducing borrowing costs(Sailendra and Israel, 2010). This is because TSA ensures that treasury-related revenue and disbursement floats in the bank are kept at minimum cost-operating level. Prior to the implementation of TSA, idle balances are maintained in several bank accounts. Effective total control of cash is also a key element in monetary and budget management (Pattanayak and Fainboim, 2011).Setting up a TSA has other objectives they include: reducing transaction costs during budget execution, notably by controlling the delay in the remittance of government revenues (both tax and nontax) from the collecting banks and making quick payments of government expenses; facilitating reconciliation between accounting and banking data; monitoring and efficient control of funds allocated to various government agencies; and facilitating better coordination with the monetary policy implementation (Pattanayak and Fainboim, 2011).

\section{Benefits of Treasury Single Account}

TSA provides a number of benefits and thereby enhances the overall effectiveness of a public financial management (PFM) system. A government without effective control over its cash resources will definitely pay for its institutional deficiencies in a multitude of ways such as incurring unnecessary borrowing costs, idle cash balances that is unproductive and in extreme cases, counterproductive etc. Sailendra and Israel (2010) in a paper titled "Treasury Single Account: Concept, Design, and Implementation issues" outlined the benefits of operating a Treasury Single Account. These benefits flow from the primary objective of its formulation which is to ensure effective aggregate control over government cash resources.

The benefits:

(i) TSA allows timely and complete information on the cas resources of the the government: In countries with settelment systems and advanced payment and an Integrated Financial Management Information System (IFMIS) which has adequate interfaces with the banking system, avails this 
information online and in real time. Also, it completes updated balances should be available daily(Sailendra and Israel, 2010).

(ii) Improves appropriation control: with TSA the Ministry of Finance maintains full control over budget allocations, and strengthens the authority of the budget appropriation. When separate bank accounts are maintained, the result is often a fragmented system, where funds provided for budgetary appropriations are augmented by additional cash resources that become available through various creative, often extra budgetary, measures(Sailendra and Israel, 2010).

(iii) Improves control of operations during budget execution: with full information about cash resources, the treasury can plan well and implement budget execution in an transparent, efficient, and reliable manner. The survival of doubt regarding whether the treasury will have enough funds to finance programmed expenditures may lead to sub-optimal behavior by budget entity, such as exaggerate their estimates for cash needs or channeling expenditures through off-budget arrangements(Sailendra and Israel, 2010).

(iv) Enables effective cash management: A TSA facilitates and ensures regular monitoring of government total cash balances. It also allows higher quality cash outturn analysis to be undertaken (example, identifying causal factors of variances and distinguishing causal factors from random variations in cash balances) (Sailendra and Israel, 2010).

(v) Reduces transaction costs and bank fees: Reducing the number of bank accounts results in lower administrative cost for the government for maintaining these accounts, including the cost associated with bank reconciliation, and reduced banking fees(Sailendra and Israel, 2010).

(vi) Facilitates effective payment mechanisms: A TSA ensures that there is no vagueness regarding the location or the volume of the government funds, and enables the precise monitoring of payment mechanisms. It can result in substantially lower transaction costs because of economies of scale in processing payments. The establishment of a TSA usually involves the elimination of the "float" in the payment and banking systems, and the introduction of transparent penalty and fee structures for payment services. Many governments have achieved considerable reductions in their real cost of banking services by introducing a TSA(Sailendra and Israel, 2010).

(vii) Improves bank quality and reconciliation of fiscal data: A TSA allows for efficient reconciliation between the cash flow statements and the government accounting systems from the banking system. This decreases the risk of errors in the process of reconciliation, and improves the timeliness and quality of the fiscal accounts (Sailendra and Israel, 2010).

(viii) Lowers the need for liquidity reserve:A TSA reduces the volatility of cash flows through the treasury, thus allowing it to maintain a lower cash reserve/buffer to meet unexpected fiscal volatility (Sailendra and Israel, 2010).

Thus far, it is obvious that the primary merits of a TSA is the mechanism it provides for proper monitoring of government receipts and expenditure. In the Nigerian case, they are in accordance with the directive of the Nigerian government when introducing the arrangement, this measure is specifically to promote transparency and facilitate compliance with sections 80 and 162 of the 1999 Nigerian Constitution. It is believed thatit will help to block most if not all the leakages that have been the bane of economic growth. We have a condition where some MDA's manage their finances like Remit Limited and Iindependent Empire to treasuries of the government. Under a appropriately run TSA, this is not conceivable as government aagencies are meant to spend funds from duly approved budget provisions. The government's maintenance of a single account will enable the Ministry of Finance monitor fund flow as no agency of government is allowed to maintain any operational bank account outside the oversight of the ministry of finance (Sailendra and Israel, 2010).

Finally, the implementation of this programme therefore is a critical step towards curbing corruption in public finance. It is in line with the commitment of the present administration to combat corrupt practices, eliminate indiscipline in public finance and ensure adequate fund flow that will be channeled to critical sectors of the economy to catalyze development. Nigerians are enthusiastic at the directive by the President Buhari as this will mean that 
DOI: $\underline{10.51386 / 25815946 / i j s m s-v 4 i 3 p 123}$

some government agencies that have been known to be withholding funds from the Federal Government are now under compulsion to remit monies to federal treasuries. These agencies include: Nigeria Customs Service (NCS), Nigerian National Petroleum Corporation (NNPC), Nigerian Ports Authority (NPA), Federal Inland Revenue Service (FIRS), Nigeria Immigration Service (NIMS), Nigerian Maritime Administration and Safety Agency (NIMASA), Federal Airport Authority of Nigeria (FAAN) amongst others (Stalwart Report. 2015).

\section{Challenges of Treasury Single Account}

With the TSA policy, the ability of banks to create money would be limited or hampered,ideally, when banks have excess of funds they use it to trade. When this reserved deposit money is moved from money deposit bank to the central bank, sterilization is created and the ability to create more money or credit is hampered, meaning that the prospect of borrowing will naturally vanished. Banks would not only have liquidity problem, it would stifle growth because they would not be able to create credit. Therefore, the economy may go into a new phase of recession depending on the severity. There are already job losses because most of the banking process has been reduced substantially (Chukwu, 2015).

Another major challenge in the implementation of TSA is resistance from MDA's which is caused by a variety of reasons, some simply due to psychological resistance to change, while others because their loopholes to perform fraudulent activities have been blocked (Eme; Okechukwu, I. Chukwurah and Daniel, C. (2015).Also, this reduction of excess funds, will pose serious cash crunch and liquidity challenges to the banking sector, which prior to the introduction of the TSA feed fat on the float created by the unaccounted and duplicated MDAs accounts scattered in various Deposit Money Banks (DMBs) in Nigeria. Possibly this will compel the banks to focus on the funding of the real sector of the economy, rather than financing heavy Federal Government projects, forex dealing, Oil and Gas transactions etc. Any DMBs that fails to look inwards to face the core banking functions and adapt swiftly which they were licensed to carry out, will definitely no longer be profitable, which will leads to heavy downsizing of staff and thereby increasing the unemployment rate in the country (Tayo, A., 2015).

\section{Treasury Single Account and Fraud Management in Nigeria Public Enterprises}

In Nigeria, section 80 sub-section 1 and section 162, sub-section 1 of the 1999 constitution of the federal government and further stated in the Executive Order No. 55 (2011), of a TSA which specified that the Bureau of Treasury (BTr) shall operate a TSA to receive remittance of collections of customs duties/ internal revenue taxes from Bureau of Customs (BOC)/ Bureau of Internal Revenue (BIR) authorised agent banks as well as other National Government Agencies from authorized government depository banks (Isa, 2016, Tari, Myatafadi and Kibikiwa, 2016). The TSA, which shall be upheld at the Central Bank of Nigeria (CBN), is believed to give credence to government in the management and control of its cash resources and pave way for the unification of the structure of government bank accounts to enable consolidation and optimal utilization of government finances.

However, section 22(1) which mandates all the revenue generating Ministries, Departments and Agencies (MDAs) to remit 80 percent of their operating surplus to the Consolidated Revenue Fund Account, allowed these MDAs to fraudulently resort to driving their so-called operating costs so high. This allows them to declare close to zero operating surpluses and as a result, 80 per cent of their remittance to government treasury becomes close to zero naira (Eme; Okechukwu, Chukwurah and Daniel, 2015). Again, this blank gap has made it possible for revenue generating MDAs to have reportedly generated N3.06 trillion in 2009, but only remitted N46.80 billion to government coffers; generated N3.07 trillion in 2010 but remitted mere N54.10 billion; and generate N3.17 trillion in 2011 and just remitted a meager N73.80 billion. As well as the case of NNPC and its subsidiaries, which have internally generated N6.132 trillion between 2009 and 2011 remitted zero naira to the government treasury (Eme et.al, 2015). The practice led to pockets of idle cash balances held in ministries, departments and agencies (MDAs)' accounts when government was out borrowing money, while creating easy avenues for fraudulent activities (Obinna, 2015). The idea of TSA came into being when some agencies refused to declare and remit 25 percent of their main annual generated revenue to the treasury as demanded by law. According to Daily Trust Editorial report (2015), 
DOI: $\underline{10.51386 / 25815946 / i j s m s-v 4 i 3 p 123}$

Volume: 4 Issue: 3

May to June 2021

www.ijsmsjournal.org

about N120 billion was forcefully recovered by government in 2012 from MDAs being 25 percent of their gross revenue to the treasury while another N34 billion was recovered in 2013.

In the last few years, academic scholars and experts in the field of strategic financial management have attempted todemonstrate the link between a TSA and fraud management. Such studies have argued that TSA is bound to improve transparency and accountability in public finance management by removing organisational secrecy around the management of public finances. Accordingly, the discretionary aspect of accounting officers and politicians collaborating to do all manner of business with government finances before executing projects thereby causing delays or negotiating interest rates with banks for private gains will be over due to the implementation of TSA. Also, the revenue generating agencies that have been depriving the treasury of due revenue through a plethora of bank accounts under their purview and which is not known to the authorities will no longer be able to defraud the revenue since all funds will be swept into the TSA. Thus, beyond accountability and transparency, the TSA will introduce economy and efficiency into overall management of public finances and this will in the long run lead to effectiveness of government spending since it places government in a better position to realise overall policy goals (Okechukwu; Chukwurah; Daniel and Iheanach, 2015, Isa, 2016). While the above argument holds, some scholars have also expressed serious concern on the negative effect of a TSA on productivity and aggregate economic development. The contention is that a TSA will drain banks of liquidity and hamper their chances of credit creation for business stimulation and growth. Besides, it will also delay financial decisions for government institutions and slowdown pace of work due to difficulties in accessibility of funds for routine activities.

Obviously, from the foregoing, the primary benefit of a TSA is the mechanism it provides for proper monitoring of government income and expenditure. In Nigeria, it will ensure the blockage of most if not all the leakages that have been the problem of the growth of the economy. Under a correctly run treasury single account, this is not probable as agencies of government are meant to spend in line with duly approved budget provisions. TSA is mainly designed to bring all Government funds in bank accounts within the effective control and operational oversight of the Treasury, in order to: Enthrone centralized, accountable and transparent revenue management; Facilitate effective cash management; Ensure cash availability; Promote efficient management of domestic borrowing at minimal cost; Allow optimal investment of idle cash; Block loopholes in revenue management; Establish an efficient disbursement and collection mechanism for Government funds; Improve liquidity reserve; and Eliminate operational inefficiency and costs associated with maintaining multiple accounts across multiple financial institutions (CBN, 2015)

\section{Theoretical and Empirical Review}

\section{Theoretical Underpinning}

In this study, the incremental public policy model inspired the framework for studying treasury single account and fraud management in public enterprises. In this model, a policy is a continuation of previous policies with minimum changes. Incrementalism refers to the method of public policy by which a wide range of small policy changes are enacted over time in order to create a larger broad based policy change (Badejo et al; 2017). It is a theoretical policy of rationality developed by Lindblom to be seen as a middle way between the rational actor model and bounded rationality, as both long term goal driven policy rationality and satisficing were not seen as adequate. Put differently, Incrementalism is a theory developed out of the realization that truly rational decision making is practically impossible given the complexity of the policy environment. That is not to say that policy actors do not have the intent to be rational: their decisions are goal-orientated and there are processes followed to achieve those goals (Eme and Chukwura, 2015). The departure from complete rationality because of its failings, Simon developed the concept of bounded rationality in decision making: humans desire true rationality, but due to cognitive limitations and the incompleteness of knowledge, decision making behavior is "satisficing" rather than maximizing benefits over costs. Charles Lindblom adopted Simon's ideas about decisionmaking and applied them to the policy process which is the basis for incrementalism (Lindblom and Woodhouse, 1993). 
DOI: $\underline{10.51386 / 25815946 / i j s m s-v 4 i 3 p 123}$

The existing programmes, policies and decisions are considered as a base or reference and policymakers accept the legitimacy of previous policies because of the uncertainty about future policies. Incremental theory of public policymaking is premised on the way and manner policy makers and government think when there is a need for them to make decision as affecting generality. These decisions are made in a condition not too conducive for more deliberation and testing of such proposed policy. Ikelegbe (1995) suggest that, policy makers using incremental model do not reviewsocietal values and problems and all policy alternatives and their resultant consequences. Howlett and Ramesh (2003) state that, incremental model relies upon a relatively stable policy background, rather than situations, where significant new data and problem identification are required.

Dlakwa (2014) says that due to constraints in time, limited intellectual ability and cost implication, decision makers are unable to sample everybody's opinion on every given issue, nor are they in the best position to identify all the alternative ways of resolving problems before they could choose the best alternative. This philosophy proposes five distinct characteristics of incremental model they are:

- First, it increases in the sense that only small steps are taken at a time in other to achieve specific objectives.

- Second, it is non-comprehensive because of the limitation imposed on policymakers by lack of resources to go into sufficient detail of problems before taking remedial actions.

- Third, policy decision involves successive comparisons because policy is never made once.

- Fourth, in practice, decision making suffices rather than maximizes from among the available options. This means that the policy maker can only solve a tiny bit of the problem and there could be a lot of errors committed by him in making such policy choice.

- The last characteristic is plurality in choice. This is based on the fact that government decision making rest on a pluralist conception of the public sector in which many contending interest groups compete for influence on our policy issues, continually forcing the administrator, as a person in the middle, to secure agreement from among the competing parties (Dlakwa 2014).

The introduction of TSA in Nigeria as a public policy follows the incremental model of policymaking because of the normative nature of its implementation though it was partially built on the prevailing experimental policy of former administration of Goodluck Ebele Jonathan in 2014, the Buhari administration translates it into a fullfledged financial policy.Therefore, the TSA is considered a system that fits modern cash management and is an effective tool for government to establish oversight and centralised control over government's cash resources. In other words, the TSA provides a number of other benefits and thereby enhances the overall effectiveness of a Public Financial Management (PFM) system. The establishment and compliance to a TSA should, therefore, receive priority in any PFM reform agenda

\section{Empirical Review}

The implementation of a TSA in Nigeriais just emerging and as such, very limited empirical studies exist in this dimension. However, some of the surviving literatures include amongst others;

Bashir (2016) evaluated the effects of Treasury Single Account on Public Finance Management in Nigeria. The study examined the extent to which Treasury Single Account can block financial leakages, promotes transparency and accountability in the public financial management. Both primary and secondary data was employed. The populations of study were drawn from Ministries, Department and Agencies (MDAs) within Bauchi metropolis and a sample of 72 respondents were chosen through judgment sampling technique. Pearson Correlation technique was used to analyse using the Pearson Correlation techniques. The result of this research showed that adoption of a Treasury Single Account (TSA) is capable of plugging financial loopholes, promoting transparency and accountability in the public Financial System. The study recommends that for the success of this policy government should promulgate more legislation tomake it mandatory for all the three tiers of government in Nigeria. 
DOI: $\underline{10.51386 / 25815946 / \mathrm{ijsms}-\mathrm{v} 4 \mathrm{i} 3 \mathrm{p} 123}$

Kanu (2016) assessed the positive effect of implementation of TSA on the Economy, the public accounting system and the undesired consequences on the liquidity base and presentation of banking sector in Nigeria. The populations of the study were drawn from 24 banks in Nigeria and the samples of ten banks were chosen through descriptive and inferential statistics. The data were analyzed using Chi-square. The results obtained established that the implementation of TSA in the public accounting system impacted negatively on the liquidity base and the performance of banking sector in Nigeria. The study recommends that CBN and the Government should come up with an arrangement to address the issue of TSA considering the impact of the activities as the important factor for efficient management, control of government's cash resources as well as sustainability of banks.

Badejo et al (2017) using exploratory study of the nexus of TSA policy in Nigeria: an exploratory discourse observed that the implementation of the policy is critical towards curbing financial leakages, excesses as in public finance, it eliminates financial indiscipline and ensure adequate fund flow that will be channeled to critical sectors of the economy. Thus guiding government in its' spending and receipts towards accelerating the rate of national growth and development. This is made in line with trajectory of the extant mismanagement of government resources. The study drew references from previous experiences of developed countries such as France, UK and other countries.

Oyedokun (2016) using meta-analysis to study the imperative of TSA in Nigeria focusing on public federal institutions as the case study reported mixed results. He recommended TSA for the prevention of fraudulent activities and enable government to monitor its resources at a glance. He further noted that despite the legion of benefits of TSA, its challenges are abound in Nigeria. Though, care must be taken in order not to allow the unenthusiastic effect of TSA to overpower the meaning of government.

\section{METHODOLOGY}

The research adopts survey method and design. There a of this study consists of Enugu, Imo and Ablactates, Nigeria. These states were selected because they have the highest concentrated number of public enterprises. The population of the work consists of 139 respondents who are employees of Corporate Affairs Commissions in SouthEast, Nigeria working at the various regional head-office branches which were selected purposively. The researcher determined the size of the sample. A total of 104 samples were derived from the study population with the use of Trek formula. Data for this study were collected mainly from primary source through questionnaire that was selfadministered. The data were analyzed by Pearson Moment Correlation and linear regression statistical test at $5 \%$ level of significance to test stated hypothesis using SPSS. We developed the answer options for the questionnaire using Liker scale with: SA-Strongly Agree, A-Agree, U- Uncertain, D - Disagree, SD - Strongly Disagree.

\section{ANALYSIS, RESULTS \& DISCUSSION}

Two hypotheses were formulated and are tested as follow using Pearson Product Moment Correlation Coefficient and Linear Regression. Hypothesis one was tested with Pearson Product Moment Correlation Coefficient while hypothesis two was tested with Linear Regression. SPSS was used to analyze the various tests.

\section{Hypothesis 1}

$\mathbf{H}_{\mathrm{A} 1}$ : $\quad$ TSA significantly reduced the incidence of fraud in public enterprises.

The result of the analysis is presented in the table below using descriptive statistics and correlation analysis:

Table 1: Descriptive Statistics of the relationship between Treasury Single Account and Fraud Management

\begin{tabular}{|l|l|l|l|}
\hline & Mean & Std. Deviation & N \\
\hline TSA & 3.8900 & 1.10914 & 100 \\
Fraud Management & 3.9700 & 1.05844 & 100 \\
\hline
\end{tabular}

Source: SPSS version 23 computation 
DOI: $\underline{10.51386 / 25815946 / \mathrm{ijsms}-\mathrm{v} 4 \mathrm{i} 3 \mathrm{p} 123}$

Volume: 4 Issue: 3

May to June 2021

www.ijsmsjournal.org

Table 2: Correlation between TSA and Fraud Management

\begin{tabular}{|ll|l|c|}
\hline & & TSA & Fraud Management \\
\hline TSA & Pearson Correlation & 1 & $.969(* *)$ \\
& Sig. (2-tailed) & .000 & .000 \\
Fraud Management & N & 100 & 100 \\
& Pearson Correlation & $.969(* *)$ & 1 \\
& Sig. (2-tailed) & .000 & 100 \\
& $\mathrm{~N}$ & 100 & \\
\hline
\end{tabular}

Source: SPSS version 23 computation

Table (1) shows the descriptive statistics of the relationship between Treasury Single Account and Fraud Management with a mean of 3.8900 and a standard deviation of 1.10914 for TSA and a mean response of 3.9700 and standard deviation of 1.05844 for Fraud Management. By careful observation of standard deviation values, it can be said that there is about the same variability of data points amongst the dependent and independent variables.

Table (2) is the Pearson correlation matrix of the relationship between TSA and Fraud Management showing the correlation coefficient, significant values and the number of cases. The correlation coefficient shows 0.969 , this value indicated that the correlation is significant at 0.05 level (2tailed) and implies that TSA significantly reduced the incidence of fraud in public enterprises, $(\mathrm{R}=0.969)$. However the computed correlation coefficient is greater than the table value of $\mathrm{R}=0.195$ with 98 degree of freedom $(\mathrm{df}=\mathrm{n}-2)$ at alpha level for a two tailed test $(\mathrm{R}=0.969$, $\mathrm{p}<.05)$. This result indicated that TSA significantly reduced the incidence of fraud in public enterprises hence alternate hypothesis should be accepted.

For the second objective, the understated hypothesis was formulated Hypothesis 2

$\mathbf{H}_{\mathbf{A 2}}$ : $\quad$ TSA in public enterprises to a large extent reduces the credit creation of deposit money banks. The results are presented below;

Table 3: Descriptive Statistics of the impact of TSA in public enterprise on credit creation of deposit money banks

\begin{tabular}{|l|l|l|l|}
\hline & Mean & Std. Deviation & N \\
\hline TSA & 3.8700 & 1.18624 & 100 \\
Credit creation of DMB & 3.6100 & 1.22181 & 100 \\
\hline
\end{tabular}

Source: SPSS version 23 computation

Table 4: Regression result between TSA in public enterprise and credit creation of deposit money banks

\begin{tabular}{|c|c|c|c|c|c|c|c|c|}
\hline \multirow[t]{2}{*}{ Particulars } & \multirow[t]{2}{*}{$\mathrm{R}$} & \multirow[t]{2}{*}{$\mathrm{R}^{2}$} & \multirow[t]{2}{*}{ Adj. $R^{2}$} & \multirow[t]{2}{*}{ DW } & \multicolumn{2}{|c|}{$\begin{array}{l}\text { Standard } \\
\text { Coefficient }\end{array}$} & \multirow[t]{2}{*}{ F-stat } & \multirow[t]{2}{*}{ Sig. } \\
\hline & & & & & Beta & T-Value & & \\
\hline TSA & $0.933^{\mathrm{a}}$ & 0.871 & 0.870 & 0.406 & 0.933 & 25.749 & 662.994 & 0.000 \\
\hline
\end{tabular}

Source: SPSS version 23 computation

$\mathrm{R}=$ Correlation Coefficient or Beta

$\mathrm{R}^{2}=$ Coefficient of Determination

Adj. $\mathrm{R}^{2}=$ Adjusted Coefficient or Determination

DW= Durbin Watson (d) test statistics

$\mathrm{T}-$ Value $=$ Student t-test statistics 
DOI: $\underline{10.51386 / 25815946 / i j s m s-v 4 i 3 p 123}$

Volume: 4 Issue: 3

May to June 2021

www.ijsmsjournal.org

$\mathrm{F}=$ test statistics

Model Equation $=0.599+0.906$

The result indicated that TSA in public enterprises to a large extent reduces the credit creation of deposit money banks as $t=25.749$ which is above the rule of thumb positivity of 2 and coefficient of TSA (0.599). The variations from the model as indicated from the coefficient of determination $\left(\mathrm{R}^{2}\right)$ value of 0.871 . Also, the result showed that TSA in public enterprises impacted negatively on the credit creation of deposit money banks as indicated by R value of 0.933 which is the same with the value of Beta 0.933 .

\subsection{Discussion of Findings}

From the specific hypotheses tested, the following are the findings:

i TSA significantly reduced the incidence of fraud in public enterprises (correlation coefficient of R value $=0.969$ and $\mathrm{P}<0.05$ ). The same result was obtained by Basir (2016)in his study the extent to which Treasury Single Account can block financial leakages, promotes transparency and accountability in the public financial management. The result showed that adoption of a Treasury Single Account (TSA) is capable of plugging financial loopholes, promoting transparency and accountability in the public Financial System in Nigeria.

ii TSA in public enterprises to a large extent reduces the credit creation of deposit money banks ( $\mathrm{R}$ value of 0.933 ; $\mathrm{t}=25.749 ; \mathrm{P}<0.05)$. The same result was obtained by Kanu (2016) who assessed the positive effect of implementation of TSA on the Economy, the public accounting system and the undesired consequences on the liquidity base and performance of banking sector in Nigeria. The results gotten confirmed that the implementation of TSA in the public accounting system impacted negatively on the liquidity base and the performance of banking sector in Nigeria.

\section{Conclusions and Recommendation}

The outcome of the analysisof this study provides strong evidence to substantiate the fact that there is a significant relationship between TSA and fraud management in Nigeria. The major objective basis for the above deduction hinges on the result of test of the two hypotheses. Along this line, one significant conclusion is deduced,while anecdotal arguments could hold against TSA implementation in Nigeria due to perceived negative effects on the banking sector, for government's effective finances and proper management of the financial institution specifically in emerging economies such as Nigeria, TSA is a very welcomed government initiative whose relevance cannot be overemphasized.

Based on the findings of this study as well as the above conclusion, the following recommendations are hereby presented to fast track the value added impact of TSA in Nigeria and the developing nations:

1. The Fiscal Sunshine bill (FSB) needs to be in place for the TSA policy to be effective, thus if enacted will open up all the financial activities of government and there will be no more hiding place for those who diversion or loot government money.

2. Government should handle all challenges encountered by the Federal Ministry of Finance and CBN and enforce the use of TSA.

\section{Contribution to Knowledge}

The article will contribute to existing knowledge in two main ways. First, it will serve as a useful tool for cash management, helping to dispel the notion that TSA would have an adverse effect on the economy, enlightening the general public on the benefits of TSA to the economy of the country. It will also be beneficial to policy makers in decision making concerning management of public finance. Second, the examination of the impact of TSA on fraud prevention and management is under-searched especially in Nigeria, yet important to policymakers and government, 
DOI: $\underline{10.51386 / 25815946 / i j s m s-v 4 i 3 p 123}$

Volume: 4 Issue: 3

May to June 2021

www.ijsmsjournal.org

the study will therefore add to the current scope of knowledge and theory to scholars interested in carrying out further research in this field.

\section{References \& Appendices}

[1] Adeolu, I. A. (2015). Understanding the treasury single account (TSA) system:Things you should know.Business and Economy Market Development.

[2] Badejo, B.A, Oluwaseyi A.A \& Taiwo M.R. (2017): The Nexus of Treasury Single Account Policy in Nigeria: an exploratory discourse

[3] Bashir, Y. M. (2016). Effect of treasury single account on public finance management in Nigeria: Research Journal of finance and Accounting, vol.7, No. 6.

[4] Chukwu, J. (2015).Treasury single account: Giving life to Jonathan's dead policy directives.Guardian Newspapers August 16.

[5] Daily Trust Editorial report (2015). Buhari on Treasury Single Account, Guardian, August 28, P16.

[6] Dlakwa HD (2014). Concepts and Models in Public Policy Formulation and Analysis, Kaduna: Pyla-Mak Services Ltd

[7] Eme; Okechukwu, I. Chukwurah and Daniel, C. (2015). An analysis of pros and cons treasury single account policy in Nigeria: Arabian Journal of Business and Management Review Vol. 5, No.4.

[8] Howlett, M. and Ramesh, M.(2003). Studying Public Policy: Policy Cycles andPolicy Subsystems. Toronto: Oxford University Press.

[9] Ikelegbe AO (1995). Public Policy Making and Analysis, Benin City: Uri Publishing Ltd.

[10] Isa, A. A. (2016). The treasury single account (TSA) as an instrument of financial prudence and management: Prospects and problems. Research Journal of Finance and Accounting,vol.7, No.4

[11] Kanu, C. (2016). Impact of Treasury Single Account on the liquidity. ABC Journal of Advanced Research, Volume 5, 43-52.

[12] Lan, L. (2009). Modernizing cash management. International Monetary Fund, imf.org.

[13] Nelson C. and Orioha, L., (2016). TSA and the Challenge of Resource Allocation. The Guardian, 25 January 2016

[14] Obinna, C. (2015). Banks Face Liquidity Strain as FG Fully Enforces Treasury Single Account, Thisday Monday, 11 August, Pp.52.

[15] Odekunle, F. (2015). Tackling Corruption in Nigeria: Strategic and Operational Options for the Buhari Administration. Being a paper delivered at the 5th Convocation Lecture of Al-Hikmah University, Ilorin on Saturday, $12^{\text {th }}$ September, 2015.

[16] Okechukwu .E; Chukwurah .I; Daniel C. \&Iheanacho. N, (2015). An analysis of pros and cons treasury single account policy in Nigeria: Arabian Journal of Business and Management Review (OMAN Chapter) Vol. 5, No.4.

[17] Onyekpere, E. (2015). Implementing the Treasury Single Account. https.//candidtakes.wordpress.com $17^{\text {th }}$ August, 2015.

[18] Pattanayak, S. \& Fainboim, I. (2011).Treasury Single Account: An essential tool for government cash management, IMF Technical Notes and Manual10/143.

[19] Sailendra, P. \& Israel, F. (2010). Treasury Single Account: Concept, design and implementation issues. International Monetary Fund Working Paper, 10 (143).

[20] Stalwart Report (2015). Treasury Bills: Easy and Safe Way of Accumulating Wealth. 17 $7^{\text {th }}$ August,2015.

[21] Tandberg, M.E., (2005). Treasury System Design: A Value Chain Approach (No. 5-153). International Monetary Fund.

[22] Tari, V. A; Myatafadi, P. \& Kibikiwa, M. G. (2016). Treasury single account (TSA) policy in Nigeria: Reviving Jonathan's dead policy directives. Online Journal of Social Sciences Research, vol.5 pp.6-12.

[23] Tayo, A. (2015). Implication of treasury single account on Nigeria economy, Newsverge.com October, 2.

[24] Yusuf, I.A \& Chiejina, N. (2015). Anti-Graft War: One Economy, One Account, Sunday Nation, August 16, Pp. 9-10 \&71. 
Appendix 1: Sample Size Determination

$\mathrm{n}=\underline{\left(1.96^{2} \times 0.5 \times 0.5\right)+0.05^{2}}$

$$
0.05^{2}+(1.96 \times 0.5 \times 0.5 / 142)
$$

$\mathrm{n}=\underline{0.9604+0.0025}$

$0.0025+0.9604 / 142$

$\mathrm{n}=\underline{0.9629}$

$0.0025+0.0067634$

$\mathrm{n}=\underline{0.9629}$

0.0092634

$\mathrm{n}=103.9$ Approximately 104

Appendix 2: Stratification of sampled staff

Table 1 Questionnaire Distributed to and Returned from the Sampled Staff

\begin{tabular}{|l|l|l|l|l|}
\hline Category & Distributed & \% & Returned & \% \\
\hline Top Management & 15 & 14.4 & 14 & 14 \\
\hline Middle Managers & 41 & 39.4 & 39 & 39 \\
\hline Junior Staff & 48 & 46.2 & 47 & 47 \\
\hline Grand Total & $\mathbf{1 0 4}$ & $\mathbf{1 0 0}$ & $\mathbf{1 0 0}$ & $\mathbf{1 0 0}$ \\
\hline
\end{tabular}

Source: Field Survey (2016)

Appendix 3: Age Structure of the Respondents

\begin{tabular}{|l|l|}
\hline Age Limits & Total \\
\hline Below 25 & 6 \\
\hline $25-34$ & 31 \\
\hline $35-44$ & 38 \\
\hline $45-54$ & 11 \\
\hline 55 Above & 14 \\
\hline Grand Total & $\mathbf{1 0 0}$ \\
\hline
\end{tabular}

Source: Field Survey (2016)

APPENDIX 4: Sex Distribution of the Sampled Staff

\begin{tabular}{|l|l|l|l|}
\hline Category & Male & Female & Total \\
\hline Top Management & 10 & 4 & 14 \\
\hline Middle Managers & 27 & 12 & 39 \\
\hline Junior Staff & 24 & 23 & 47 \\
\hline Grand Total & $\mathbf{6 1}$ & $\mathbf{3 9}$ & $\mathbf{1 0 0}$ \\
\hline
\end{tabular}

Source: Field Survey (2016) 
DOI: $\underline{10.51386 / 25815946 / \mathrm{ijsms}-\mathrm{v} 4 \mathrm{i} 3 \mathrm{p} 123}$

Volume: 4 Issue: 3

May to June 2021

www.ijsmsjournal.org

APPENDIX 5: Educational Status of the Respondent

\begin{tabular}{|l|l|l|l|l|l|l|}
\hline Category & SSCE /Eqv & OND/Eqv & B.Sc./Eqv & MBA/Eqv & Ph.D/Eqv & Total \\
\hline Top Management & - & - & - & 9 & 5 & 14 \\
\hline Middle Managers & - & - & 22 & 19 & 2 & 39 \\
\hline Junior Staff & 15 & 32 & - & - & - & 47 \\
\hline Grand Total & 15 & 32 & 22 & 28 & 7 & 100 \\
\hline
\end{tabular}

APPENDIX 6: Objective one:To determine the effect of TSA on fraud management in public enterprises.

\begin{tabular}{|c|l|l|l|l|l|l|l|}
\hline & OPTION & SA & A & U & D & SD & TOTAL \\
\hline 1. & $\begin{array}{l}\text { With Treasury Single Account policy, all the } \\
\text { money made in my organization is being } \\
\text { remitted to one account which is federal account. }\end{array}$ & & & & & \\
\hline 2. & $\begin{array}{l}\text { There is no room for fraudulent act in my } \\
\text { organization since the execution of TSA. }\end{array}$ & & & & & \\
\hline
\end{tabular}

APPENDIX 7: Objective Two:To assess the impact of TSA in public enterpriseson the credit creation of deposit money banks.

\begin{tabular}{|l|l|l|l|l|l|l|l|}
\hline & OPTION & SA & A & U & D & SD & TOTAL \\
\hline 3. & $\begin{array}{l}\text { My organization is no longer liable for } \\
\text { excessive credit from deposit money banks } \\
\text { since the introduction of TSA policy. }\end{array}$ & & & & & \\
\hline 4. & $\begin{array}{l}\text { TSA has prevented the chances of credit } \\
\text { creation for business stimulation and growth in } \\
\text { the economy. }\end{array}$ & & & & & & \\
\hline
\end{tabular}

\section{INTERVIEW SCHEDULE}

1. As a manager how do you see TSA?

2. Is TSA a positive policy in your organization?

3. Has TSA change anything in your organization?

4. How is your employees' response toward the new policy?

5. How effective is your organization since the implementation of TSA?

\section{Hypothesis 1}

$\mathbf{H}_{\mathrm{A1}}$ : $\quad$ TSA significantly reduced the incidence of fraud in public enterprises.

Table 7 Coded Responses on Effect of TSA on Fraud Management

\begin{tabular}{|l|l|l|l|l|l|l|l|l|}
\hline S/No & Questionnaire Item & \multicolumn{2}{l|}{ S. Agree/Agree } & \multicolumn{2}{l|}{ Undecided } & \multicolumn{2}{l|}{$\begin{array}{l}\text { Disagree/S. } \\
\text { Disagree }\end{array}$} & \\
\hline & & Freq & $\%$ & Freq & $\%$ & Freq & $\begin{array}{l}\text { Total } \\
(\text { Freq })\end{array}$ \\
\hline 1 & With Treasury Single Account policy, all & 67 & $67 \%$ & 19 & $19 \%$ & 14 & $14 \%$ & 100 \\
\hline
\end{tabular}


DOI: $\underline{10.51386 / 25815946 / i j s m s-v 4 i 3 p 123}$

Volume: 4 Issue: 3

May to June 2021

www.ijsmsjournal.org

\begin{tabular}{|c|c|c|c|c|c|c|c|c|}
\hline & $\begin{array}{l}\text { the money made in my organization is being } \\
\text { remitted to one account which is federal } \\
\text { account. }\end{array}$ & & & & & & & \\
\hline \multirow[t]{2}{*}{2} & $\begin{array}{l}\text { There is no room for fraudulent act in my } \\
\text { organization since the execution of TSA. }\end{array}$ & 71 & $71 \%$ & 18 & $18 \%$ & 11 & $11 \%$ & 100 \\
\hline & Total & 138 & $138 \%$ & 37 & $37 \%$ & 25 & $25 \%$ & 200 \\
\hline
\end{tabular}

Source: Field Work 2016 